\title{
Genomic copy number variations in glaucomatous neurodegeneration
}

\author{
Arijit Mukhopadhyay \\ From International Conference on Human Genetics and 39th Annual Meeting of the Indian Society of \\ Human Genetics (ISHG) \\ Ahmadabad, India. 23-25 January 2013
}

Copy number variation $(\mathrm{CNV})$ is one of the major factors contributing to genomic diversity and diseases. It has been shown especially for neurodegenerative diseases that $\mathrm{CNVs}$ can play a very important role in genetic predisposition of the disease. Glaucoma is a major neurodegenerative disease causing irreversible vision loss across the globe. We wanted to analyze the impact of CNVs in a genome-wide scale in patients of primary open angle glaucoma (POAG) collected from the West Bengal state of India and reproduce our results in another cohort of Caucasian origin. Genome-wide data was generated on 347 POAG cases and 345 controls on Illumina 660WQuad arrays and CNVs were called using PennCNV. The CNVs were classified as small $(<100 \mathrm{~kb})$ and large $(>100 \mathrm{~kb})$ and analyzed seprately for their involvement in the disease. A publicly available dataset of POAG cohort of 624 cases and 404 controls from Caucasian origin (GLAUGEN study) was used as a validation cohort and genome-wide CNV data of 208 HAPMAP samples was used as global control. We analyzed genome-wide CNV from 1928 samples. For the large CNVs distribution was significantly skewed toward larger size $(>1 \mathrm{Mb})$ in cases compared to controls and this was replicated in the GLAUGEN data. We found that CNVs $>1 \mathrm{Mb}$ are enriched for gene rich regions in POAG patients with 125 genes while for controls a similar percentage of large CNVs overlapped with only 5 genes. In 208 HAPMAP samples $\mathrm{CNV}>1 \mathrm{Mb}$ overlapped with 95 genes. Interestingly, genes found in the patients were unique and did not overlap with controls or HAPMAP samples. Within CNVs of $>1 \mathrm{Mb}$ gene-rich large deletions were $\sim 2$ fold enriched in patients compared to duplications irrespective of their ethnic background. Such a bias was not observed in the controls. In the smaller $\mathrm{CNV}$ range we performed

Correspondence: arijit@igib.in

CSIR-Institute of Genomic and Integrative Biology, New Delhi, India association analysis and identifed novel regions to be under significantly higher $\mathrm{CNV}$ in patients' comapred to controls. Particularly, a CNV encompassing the transcription factor FOXE3 was significantly enriched in patients of both Indian and Caucasian POAG patietns comapred to their respective controls. A sequence analysis of the gene revealed novel missense mutation in the patients. We have shown that genomic $\mathrm{CNVs}>1 \mathrm{Mb}$ has significantly higher burden in POAG patient's genome compared to controls irrespective of the population background. We have also identified candidate genes/regions which are uniquely present in POAG cases and absent in controls from all over the world. Our data provide new insights into role of $\mathrm{CNV}$ in pathogenesis of POAG.

Published: 21 January 2014

\section{doi:10.1186/1755-8166-7-S1-I33}

Cite this article as: Mukhopadhyay: Genomic copy number variations in glaucomatous neurodegeneration. Molecular Cytogenetics 2014 7(Suppl 1):133.

Submit your next manuscript to BioMed Central and take full advantage of:

- Convenient online submission

- Thorough peer review

- No space constraints or color figure charges

- Immediate publication on acceptance

- Inclusion in PubMed, CAS, Scopus and Google Scholar

- Research which is freely available for redistribution

Submit your manuscript at www.biomedcentral.com/submit
() Biomed Central 